\title{
Effect of the support on cobalt carbide catalysts for sustainable production of olefins from syngas
}

\author{
Xinxing Wang a,b, Wen Chen a, Tiejun Lin a , Jie Li a, Fei Yu a,b, Yunlei An a,b, Yuanyuan Dai a,b, Hui Wanga, \\ Liangshu Zhong a,c,*, Yuhan Sun a,c \\ a CAS Key Laboratory of Low-Carbon Conversion Science and Engineering, Shanghai Advanced Research Institute, Chinese Academy of Sciences, Shanghai \\ 201203, China \\ b University of Chinese Academy of Sciences, Beijing 100049, China \\ ' School of Physical Science and Technology, ShanghaiTech University, Shanghai 201203, China
}

\section{A R T I C L E I N F O}

\section{Article history:}

Received 2 July 2018

Accepted 31 July 2018

Published 5 December 2018

\section{Keywords:}

Fischer-Tropsch to olefins

Cobalt carbide

Supported catalyst

Olefin

Syngas

\begin{abstract}
A B S T R A C T
$\mathrm{Co}_{2} \mathrm{C}$-based catalysts with $\mathrm{SiO}_{2}, \gamma-\mathrm{Al}_{2} \mathrm{O}_{3}$, and carbon nanotubes (CNTs) as support materials were prepared and evaluated for the Fischer-Tropsch to olefin (FTO) reaction. The combination of catalytic performance and structure characterization indicates that the cobalt-support interaction has a great influence on the $\mathrm{Co}_{2} \mathrm{C}$ morphology and catalytic performance. The CNT support facilitates the formation of a CoMn composite oxide during calcination, and $\mathrm{Co}_{2} \mathrm{C}$ nanoprisms were observed in the spent catalysts, resulting in a product distribution that greatly deviates from the classical Anderson-Schulz-Flory (ASF) distribution, where only $2.4 \mathrm{C} \%$ methane was generated. The $\mathrm{Co}_{3} \mathrm{O}_{4}$ phase for $\mathrm{SiO}_{2}$ - and $\gamma-\mathrm{Al}_{2} \mathrm{O}_{3}$-supported catalysts was observed in the calcined sample. After reduction, $\mathrm{CoO}$, $\mathrm{MnO}$, and low-valence CoMn composite oxide were generated in the $\gamma-\mathrm{Al}_{2} \mathrm{O}_{3}$-supported sample, and both $\mathrm{Co}_{2} \mathrm{C}$ nanospheres and nanoprisms were identified in the corresponding spent catalyst. However, only separated phases of $\mathrm{CoO}$ and $\mathrm{MnO}$ were found in the reduced sample supported by $\mathrm{SiO}_{2}$, and $\mathrm{Co}_{2} \mathrm{C}$ nanospheres were detected in the spent catalyst without the evidence of any $\mathrm{Co}_{2} \mathrm{C}$ nanoprisms. The $\mathrm{Co}_{2} \mathrm{C}$ nanospheres led to a relatively high methane selectivity of $5.8 \mathrm{C} \%$ and $12.0 \mathrm{C} \%$ of the $\gamma-\mathrm{Al}_{2} \mathrm{O}_{3}$ - and $\mathrm{SiO}_{2}$-supported catalysts, respectively. These results suggest that a relatively weak cobalt-support interaction is necessary for the formation of the CoMn composite oxide during calcination, which benefits the formation of $\mathrm{Co}_{2} \mathrm{C}$ nanoprisms with promising catalytic performance for the sustainable production of olefins via syngas.
\end{abstract}

(C) 2018, Dalian Institute of Chemical Physics, Chinese Academy of Sciences. Published by Elsevier B.V. All rights reserved.

\section{Introduction}

Olefins, as basic building blocks of the chemical industry, are extensively used to synthesize various products such as polymers, solvents, drugs, cosmetics, and detergents [1-5]. Traditionally, olefins are produced by thermal or catalytic cracking of petroleum products such as naphtha, gas oil, and condensates. Due to the expected depletion of limited petroleum reserves, it is necessary to develop new processes that can produce olefins from alternative feedstocks. Syngas, a mixture of carbon monoxide and hydrogen, can be obtained from various carbon-containing sources such as coal, natural gas, biomass,

\footnotetext{
* Corresponding author. Tel: +86-21-20608002; Fax: +86-21-20350867; E-mail: zhongls@sari.ac.cn

This work was supported by the National Key R\&D Program of China (2017YFB0602202), the National Natural Science Foundation of China (21573271, 91545112, and 21703278), the Key Research Program of Frontier Sciences, CAS (QYZDB-SSW-SLH035), the Strategic Priority Research Program of the Chinese Academy of Sciences (XDA21020600), and SARI Interdisciplinary Youth Innovation Research Funding (171001). DOI: 10.1016/S1872-2067(18)63153-5 | http://www.sciencedirect.com/science/journal/18722067 | Chin. J. Catal., Vol. 39, No. 12, December 2018
} 
and even organic waste [6-11]. Many value-added products, including methanol, gasoline, diesel, alcohols, and olefin chemicals, can be obtained from syngas conversion.

Owing to the simplified operation and low energy consumption, direct production of olefins from syngas has attracted increased attention. The typical routes of direct production of olefins from syngas include bifunctional catalytic reactions and the Fischer-Tropsch to olefin (FTO) process. During bifunctional catalytic processes, methanol-like intermediates are generated first, which are then further converted into olefins using molecular sieve catalysts [3,12-14]. Jiao et al. [13] and Li et al. [15] developed a $\mathrm{ZnCrO}_{x} / \mathrm{MSAPO}$ bifunctional catalyst and obtained a $\mathrm{C}_{2-4}=$ selectivity as high as $80 \mathrm{C} \%$ at a $\mathrm{CO}$ conversion of $17 \%$ at $400{ }^{\circ} \mathrm{C}$ and $2.5 \mathrm{MPa}$. Cheng et al. [14] reported a $\mathrm{Zn}-\mathrm{Zr} / \mathrm{SAPO}-34$ catalyst with a $\mathrm{CO}$ conversion of $10 \%$ and $\mathrm{C}_{2-4}=$ selectivity of $70 \mathrm{C} \%$ at $400{ }^{\circ} \mathrm{C}$ and $1 \mathrm{MPa}$. In addition, it was found that the integration manner and proximity of the two components are crucial for the $\mathrm{C}_{2-4}=$ selectivity [16-18]. Traditional studies of the FTO process mainly focused on Fe-based catalysts $[1,19,20]$. Torres Galvis et al. [4] studied supported iron FTO catalysts and found that $\mathrm{Fe} / \mathrm{CNF}$ and $\mathrm{Fe} / \alpha-\mathrm{Al}_{2} \mathrm{O}_{3}$ catalysts exhibit a high selectivity toward lower olefins $(\sim 60 \mathrm{C} \%)$ with relatively low methane selectivity $(<25 \mathrm{C} \%)$. The effects of the iron particle size, sodium, and sulfur on the catalytic performance of supported iron catalysts during the FTO reaction were also investigated $[5,21,22]$. The results showed that the nature and concentrations of the promoters play a key role in the design of FTO catalysts with optimum catalytic performance. However, Fe-based FTO catalysts usually require a very high temperature $\left(>300^{\circ} \mathrm{C}\right)$, which may cause catalyst deactivation due to particle sintering and carbon deposition.

Recently, we discovered that $\mathrm{Co}_{2} \mathrm{C}$ nanoprisms derived from the CoMn composite oxide could catalyze syngas conversion to lower olefins with a high selectivity of $60.8 \mathrm{C} \%$ under mild reaction conditions $\left(250^{\circ} \mathrm{C}, 1-5\right.$ bar) [23-25]. Low methane $(<5$ C\%) and high olefin selectivities with a high olefin/paraffin ratio were simultaneously obtained. Catalyst characterization and theoretical calculations indicated that $\mathrm{Co}_{2} \mathrm{C}$ nanoprisms play a key role in syngas conversion, which favors olefin production and inhibits methane formation. The effects of alkali and manganese on the catalytic performance of Co-based catalysts during the FTO reaction were also studied [24,25]. It was found that $\mathrm{Na}$, acting as an electronic donor to cobalt, promotes the formation of $\mathrm{Co}_{2} \mathrm{C}$. Manganese not only acts as typical electronic and structural promoter but also has a strong influence on the morphology of $\mathrm{Co}_{2} \mathrm{C}$ nanoprisms with special exposed (101) and (020) facets.

Supported catalysts are usually used for the Fischer-Tropsch reaction to enhance the mechanical stability and thermal conductivity and improve the dispersion of the active phase [26-28]. The effect of the chemical nature of the oxide support on the cobalt FT catalysts was investigated by Reuel et al. [29], who reported a decline in the catalytic activity per surface Co atom (or turnover frequency, TOF) in the order $\mathrm{Co} / \mathrm{TiO}_{2}$ $>\mathrm{Co} / \mathrm{SiO}_{2}>\mathrm{Co} / \mathrm{Al}_{2} \mathrm{O}_{3}>\mathrm{Co} / \mathrm{MgO}$. Keyvanloo et al. [30] reported a supported Fe-FT catalyst using $\gamma$-alumina doped with silica as the support. The catalytic performance was greatly improved compared with bulk and traditionally supported Fe-FT catalysts. Prieto et al. [31] studied the effect of the chemical nature of the oxide support on the performance of cobalt FT catalysts and observed a volcano dependence of the metal-specific activity on the nature of the support. A marked support effect on the hydrocarbon selectivity pattern was also reported by Borg et al. [7], who found that the porosity size of the $\gamma-\mathrm{Al}_{2} \mathrm{O}_{3}$ support affects the size of the $\mathrm{Co}_{3} \mathrm{O}_{4}$ nanoparticles and product selectivity.

In our previous work, $\mathrm{Co}_{2} \mathrm{C}$-based FTO catalysts were usually prepared by coprecipitation. Whether a supported Co-based catalyst prepared by impregnation is available for FTO remains unclear, in addition to its effect on the catalytic performance. In this study, $\mathrm{SiO}_{2}, \gamma-\mathrm{Al}_{2} \mathrm{O}_{3}$, and carbon nanotubes (CNTs) were selected as supports and their effects were investigated. The detailed structure of the catalysts was studied with a combination of several characterization techniques such as nitrogen adsorption, temperature-programmed reduction (TPR), X-ray diffraction (XRD), and transmission electron microscopy (TEM). The effect of the cobalt-support interaction on the $\mathrm{Co}_{2} \mathrm{C}$ morphology and catalytic performance was also discussed.

\section{Experimental}

\subsection{Catalyst preparation}

Supported Co catalysts with a nominal loading of $30 \mathrm{wt} \%$ Co (as metal Co), $14 \mathrm{wt} \% \mathrm{Mn}$ (the atomic ratio of Co/Mn is 2), and

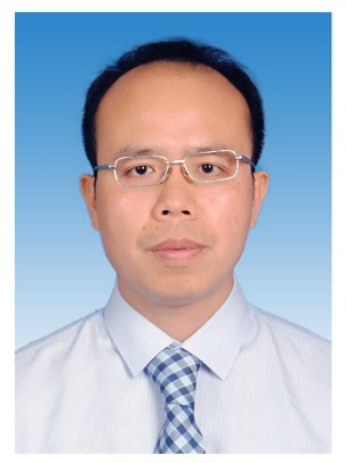

Liangshu Zhong (Shanghai Advanced Research Institute, Chinese Academy of Sciences) received the $\mathbf{6}^{\text {th }}$ Young Chemist Award in 2018, which was presented by Chinese Chemical Society and Royal Society of Chemistry. Professor Liangshu Zhong received his Ph.D. degree in Physical Chemistry from Institute of Chemistry, Chinese Academy of Sciences in 2008. After two years in Technical University of Munich as a post-doctoral fellow, he joined Shanghai Advanced Research Institute, Chinese Academy of Sciences in 2010 where he was promoted to a full professor in 2015. He has also received several awards and honours, including the Young Scientist Award of Chinese Academy of Sciences in 2017, and Outstanding Advisor Award of Chinese Academy of Sciences in 2017. His research interests are mainly focused on development of new catalyst systems with high selectivity for $C 1$ conversion via the design of new active sites and the investigation of nanoeffects. 
$2 \mathrm{wt} \%$ Na were prepared by multi-step incipient wetness impregnation of the selected support with an aqueous solution of cobalt nitrate $\left(\mathrm{Co}\left(\mathrm{NO}_{3}\right)_{2} \cdot 6 \mathrm{H}_{2} \mathrm{O}\right.$, Sinopharm Chemical Reagent Co., Ltd.), manganese nitrate ( $50 \mathrm{wt} \% \mathrm{Mn}\left(\mathrm{NO}_{3}\right)_{2}$, aq, Sinopharm Chemical Reagent Co., Ltd.), and $\mathrm{Na}_{2} \mathrm{CO}_{3}$ (Sinopharm Chemical Reagent Co., Ltd.). Different support materials were used including $\mathrm{SiO}_{2}\left(480 \mathrm{~m}^{2} / \mathrm{g}\right.$, Aladdin), $\gamma-\mathrm{Al}_{2} \mathrm{O}_{3}\left(180 \mathrm{~m}^{2} / \mathrm{g}\right.$, Sasol), and CNT (170 $\mathrm{m}^{2} / \mathrm{g}$, Sinopharm Chemical Reagent Co., Ltd.). Before impregnation, the CNT support was pretreated using the following procedure. The CNT (30 g) and 65\%-68\% $\mathrm{HNO}_{3}$ (600 mL, Sinopharm Chemical Reagent Co., Ltd.) were added to a flask $(1000 \mathrm{~mL})$, the mixture was stirred at $100^{\circ} \mathrm{C}$ for $5 \mathrm{~h}$, and the resulting suspension was filtered. The filter cake was washed with deionized water eight times and dried at $80^{\circ} \mathrm{C}$ for $12 \mathrm{~h}$.

The solution was added to the support until the pore volume was completely filled. After each impregnation step, the catalysts were dried at $80{ }^{\circ} \mathrm{C}$ for $2 \mathrm{~h}$. Impregnation and drying steps were repeated until the total volume of the solution was incorporated. The dried samples supported on $\mathrm{SiO}_{2}$ or $\gamma-\mathrm{Al}_{2} \mathrm{O}_{3}$ were calcined at $400{ }^{\circ} \mathrm{C}$ for $3 \mathrm{~h}$ with a heating rate of $1{ }^{\circ} \mathrm{C} / \mathrm{min}$ in static air, while the CNT sample was calcined under nitrogen flow.

\subsection{Catalyst characterization}

Nitrogen adsorption measurements were performed on a Micromeritics TriStar 3020 instrument. Approximately 50 mg sample was degassed at $200{ }^{\circ} \mathrm{C}$ in vacuum for $10 \mathrm{~h}$ and then moved to the analysis station for adsorption-desorption at $-196{ }^{\circ} \mathrm{C}$. The specific surface area was calculated using the Brunauer-Emmett-Teller (BET) equation. The total pore volume and average pore size were determined by the Barrett-Joyner-Halenda (BJH) method. The adsorption branches were employed for the calculations [32].

The XRD patterns of the catalysts were obtained with a Rigaku Ultima IV X-ray powder diffractometer (40 kV, $40 \mathrm{~mA})$ using $\mathrm{Cu} K_{\alpha}$ radiation $(\lambda=1.54056 \AA)$ at a scanning rate of $4 \%$ min. Subsequently, $\mathrm{H}_{2}$-TPR experiments were carried out on a Micromeritics Autochem-II 2920 instrument equipped with a thermal conductivity detector (TCD). The samples (30 mg) were pretreated under a helium flow at $200{ }^{\circ} \mathrm{C}$ for $120 \mathrm{~min}$ and then cooled to $50{ }^{\circ} \mathrm{C}$. The gas stream was then switched to $5 \%$ $(v / v) \mathrm{H}_{2} / \mathrm{Ar}$ and the temperature was raised from 50 to $800{ }^{\circ} \mathrm{C}$ at a rate of $10^{\circ} \mathrm{C} / \mathrm{min}$.

TEM measurements were performed on a JEOL JEM 2011 electron microscope with a $200 \mathrm{kV}$ accelerating voltage. The samples were prepared by dispersing the powder in ethanol followed by ultrasonication and then one droplet of the suspension was dropped on a carbon-coated copper grid for the measurement. The nanoparticle size distribution of each sample was determined using samples of $\sim 300$ nanoparticles.

\subsection{Catalytic evaluation}

The FTO reaction was carried out in a stainless fixed-bed reactor with an inner diameter of $8 \mathrm{~mm}$. A total of $1.5 \mathrm{~g}$ of the catalyst (40-60 mesh) was mixed with $3 \mathrm{~g}$ silica of the same size. Prior to the reaction, the catalysts were reduced in situ at $300{ }^{\circ} \mathrm{C}$ and 1 bar for $5 \mathrm{~h}$ in a flow of $10 \% \mathrm{CO} / \mathrm{N}_{2}(\mathrm{v} / \mathrm{v})$ with a weight hourly space velocity (WHSV) of $6000 \mathrm{~mL} \mathrm{~h}^{-1} \mathrm{gcat}^{-1}$ (where $g_{\text {cat }}$ denotes the mass of the catalyst). The heating ramp was $1{ }^{\circ} \mathrm{C} / \mathrm{min}$. After the reduction, the temperature was dropped to $265{ }^{\circ} \mathrm{C}$. A mixture of 97 vol\% syngas with different $\mathrm{H}_{2} / \mathrm{CO}(v / v)$ ratios $\left(\mathrm{H}_{2} / \mathrm{CO}=0.5,1\right.$, or 2$)$ and 3 vol\% $\mathrm{N}_{2}$ (as an internal standard) was introduced to the reactor as the feed gas. The reaction pressure was then increased to $5 \mathrm{bar}$, and the reaction was conducted at a WHSV of $2000 \mathrm{~mL} \mathrm{~h}^{-1} \mathrm{gcat}^{-1}$. The pressure of the system was kept at 5 bar using a pressure controller (TESCOM). Data were recorded after $100 \mathrm{~h}$ of reaction when reaction stability was reached.

The outlet gas was analyzed online with a GC after passing through hot $\left(120^{\circ} \mathrm{C}\right)$ and cold $\left(0^{\circ} \mathrm{C}\right)$ traps and the liquid and wax products were collected and analyzed offline (also using the GC). During the reaction, the reactor effluent was analyzed online by an Agilent 7890B gas chromatograph equipped with two columns and two detectors. The $\mathrm{H}_{2}, \mathrm{~N}_{2}, \mathrm{CO}, \mathrm{CH}_{4}$, and $\mathrm{CO}_{2}$ concentrations were analyzed by employing a TDX-1 carbon molecular sieve column with a TCD using He as the carrier gas. The $\mathrm{C}_{1}-\mathrm{C}_{7}$ hydrocarbons were analyzed with a $\mathrm{KCl}$-modified alumina capillary column (Agilent 19095P-K25) with Ar carrier gas and a hydrogen flame ionization detector (FID). Aqueous, liquid oil, and solid wax products collected from the cold and hot traps were analyzed offline with a GC (Shimadzu GC2010 plus). The $\mathrm{H}_{2} \mathrm{O}$, methanol, and $\mathrm{C}_{1}-\mathrm{C}_{5}$ oxygenates of the aqueous products were analyzed by using two Porapak $\mathrm{Q}$ columns equipped with a TCD and FID. The liquid oil products were analyzed with an HP-1 column with $\mathrm{N}_{2}$ carrier gas and FID. The solid wax products were dissolved in $\mathrm{CS}_{2}$ and analyzed with an MXT-1 column with $\mathrm{N}_{2}$ carrier gas and FID. The mass, carbon, and oxygen balances calculated for each test were $100 \% \pm 5 \%$. Further details of the GC analysis can be found in our previous studies [23,33].

For a typical FTO reaction, the CO conversion $\left(X_{\mathrm{CO}}\right)$ and product selectivity $\left(\mathrm{S}_{\mathrm{CO}_{2}}, S_{i}\right)$ were calculated based on the following equations:

$$
\begin{gathered}
X_{\mathrm{CO}}=\left(n_{\mathrm{CO}, \text { inlet }}-n_{\mathrm{CO}, \text { outlet }}\right) / n_{\mathrm{CO}, \text { inlet }} \times 100 \% \\
S_{\mathrm{CO}_{2}}=n_{\mathrm{CO}_{2}} /\left(n_{\mathrm{CO} \text {,inlet }}-n_{\mathrm{CO}, \text { outlet }}\right) \times 100 \% \\
S_{i}=\left(N_{i} \times n_{i}\right) / \sum\left(N_{i} \times n_{i}\right) \times 100 \%
\end{gathered}
$$

where $n_{\mathrm{co}, \text { inlet }}$ and $n_{\mathrm{co}, o u t l e t}$ represent the moles of $\mathrm{CO}$ at the inlet and outlet, respectively, $n_{\mathrm{co} 2}$ represents the moles $\mathrm{C}$ of $\mathrm{CO}_{2}$ at the outlet, $N_{i}$ is the molar fraction of product $i$, and $n_{i}$ is the carbon number of product $i$.

\section{Results and discussion}

\subsection{Structure characterization}

\subsubsection{Textural properties}

The BET surface area, pore size, and pore volume of the supports and the corresponding supported catalysts are listed in Table 1. The $\mathrm{SiO}_{2}$ support exhibits the highest specific surface area of $459.0 \mathrm{~m}^{2} / \mathrm{g}$. The specific surface areas of $\gamma-\mathrm{Al}_{2} \mathrm{O}_{3}$ 
Table 1

Textural properties of various supports and the corresponding catalysts.

\begin{tabular}{lcc}
\hline Sample & BET surface area $\left(\mathrm{m}^{2} / \mathrm{g}\right)$ & Pore volume $\left(\mathrm{cm}^{3} / \mathrm{g}\right)$ \\
\hline $\mathrm{SiO}_{2}$ & 459.0 & 0.78 \\
$\gamma-\mathrm{Al}_{2} \mathrm{O}_{3}$ & 184.6 & 0.52 \\
$\mathrm{CNT}$ & 170.6 & 0.57 \\
$\mathrm{CoMnNa} / \mathrm{SiO}_{2}$ & 60.7 & 0.23 \\
$\mathrm{CoMnNa} / \gamma-\mathrm{Al}_{2} \mathrm{O}_{3}$ & 72.7 & 0.21 \\
$\mathrm{CoMnNa} / \mathrm{CNT}$ & 98.4 & 0.37 \\
\hline
\end{tabular}

and CNT are 184.6 and $170.6 \mathrm{~m}^{2} / \mathrm{g}$, respectively. After impregnation, the specific surface area and pore volume decrease dramatically due to the coverage and/or blocking of the pore structure [34]. The specific surface areas of $\mathrm{CoMnNa} / \mathrm{SiO}_{2}$, $\mathrm{CoMnNa} / \gamma-\mathrm{Al}_{2} \mathrm{O}_{3}$, and $\mathrm{CoMnNa} / \mathrm{CNT}$ decrease to $60.7,72.7$, and $98.4 \mathrm{~m}^{2} / \mathrm{g}$, respectively. The pore volumes of $\mathrm{SiO}_{2}, \gamma-\mathrm{Al}_{2} \mathrm{O}_{3}$, and CNT are $0.78,0.52$, and $0.57 \mathrm{~cm}^{3} / \mathrm{g}$, respectively. However, the pore volumes of the corresponding catalysts decrease to 0.23 , 0.21 , and $0.37 \mathrm{~cm}^{3} / \mathrm{g}$ after impregnation, respectively.

\subsection{2. $X R D$}

The XRD patterns of the calcined cobalt catalysts with different supporting materials are presented in Fig. 1(a). In addition to weak diffraction peaks of the corresponding support materials, the XRD measurements of $\mathrm{CoMnNa} / \mathrm{SiO}_{2}$ and $\mathrm{CoM}$ $\mathrm{nNa} / \gamma-\mathrm{Al}_{2} \mathrm{O}_{3}$ reveal the presence of diffraction peaks corresponding to $\mathrm{Co}_{3} \mathrm{O}_{4}$ (JCPDS \#74-2120) and $\mathrm{MnO}_{2}$ (JCPDS \#81-2261). The CoMnNa/CNT shows diffraction peaks of $\mathrm{CoMn}_{2} \mathrm{O}_{4}$ (JCPDS \#77-0471) and CoO (JCPDS \#74-2391) [24,25,35].

After reduction at $300{ }^{\circ} \mathrm{C}$ (Fig. $1(\mathrm{~b})$ ), $\mathrm{CoMnNa} / \mathrm{SiO}_{2}$ shows diffraction peaks of MnO (JCPDS \#75-0257) and CoO (JCPDS \#71-1178), indicating the separation of the cobalt and manganese phases. The average crystallite size of $\mathrm{CoO}$ is $9.5 \mathrm{~nm}$ based on Scherrer's equation using the (200) peak located at $2 \theta=$ $42.4^{\circ}$. For $\mathrm{CoMnNa} / \gamma-\mathrm{Al}_{2} \mathrm{O}_{3}$, diffraction peaks of $\mathrm{Co}_{x} \mathrm{Mn}_{1-x} \mathrm{O}$ with a low degree of crystallinity at $2 \theta$ of $36^{\circ}, 42^{\circ}$, and $61^{\circ}$ were observed in addition to that of $\mathrm{CoO}$ and $\mathrm{MnO}$. However, only the $\mathrm{Co}_{x} \mathrm{Mn}_{1-x} \mathrm{O}$ phase was found in the reduced $\mathrm{CoMnNa} / \mathrm{CNT}$ catalyst. The average $\mathrm{Co}_{x} \mathrm{Mn}_{1-x} \mathrm{O}$ crystallite size in the reduced $\mathrm{CoMnNa} / \gamma-\mathrm{Al}_{2} \mathrm{O}_{3}$ and $\mathrm{CoMnNa} / \mathrm{CNT}$ is 15.4 and $23.3 \mathrm{~nm}$, respectively.

With respect to the spent catalysts (Fig. 1(c)), all samples show diffraction peaks of $\mathrm{Co}_{2} \mathrm{C}$ (JCPDS \# 65-1457) at $2 \theta$ of $41.3^{\circ}, 42.6^{\circ}$, and $45.7^{\circ}$. Based on the calculation using Scherrer's equation and the (111) peak located at $2 \theta=42.8^{\circ}$, the average sizes of the $\mathrm{Co}_{2} \mathrm{C}$ nanoparticles are 15.4, 20.8, and 23.9 $\mathrm{nm}$ for $\mathrm{CoMnNa} / \mathrm{SiO}_{2}$, CoMnNa$/ \gamma-\mathrm{Al}_{2} \mathrm{O}_{3}$, and $\mathrm{CoMnNa} / \mathrm{CNT}$, respectively. Diffraction peaks of $\mathrm{Co}_{x} \mathrm{Mn}_{1-x} \mathrm{O}$ were also observed in the spent $\mathrm{CoMnNa} / \gamma-\mathrm{Al}_{2} \mathrm{O}_{3}$ and $\mathrm{CoMnNa} / \mathrm{CNT}$ samples. In addition, diffraction peaks assigned to $\mathrm{MnCO}_{3}$ (JCPDS $\# 44-1472$ ) at $2 \theta$ of $31.4^{\circ}, 37.5^{\circ}$, and $51.7^{\circ}$ were found for $\mathrm{CoMnNa/CNT}$.

\subsection{3. $T P R$}

The TPR results for the supported catalysts are presented in Fig. 2(a). The outlet gas was detected online using a mass spectrometer. Fig. 2(b) shows the evolution of the MS signal of $m / z$ $=18\left(\mathrm{H}_{2} \mathrm{O}\right)$ vs. the reduction temperature during the TPR process. The TPR profiles fit the MS signal well, suggesting that all TPR peaks are involved in the consumption of hydrogen and formation of water. For the $\mathrm{CoMnNa} / \mathrm{SiO}_{2}$ and $\mathrm{CoMnNa} / \gamma-\mathrm{Al}_{2} \mathrm{O}_{3}$ catalysts, three distinct peaks centered at 372,427 , and $566{ }^{\circ} \mathrm{C}$ and at 326,400 , and $604^{\circ} \mathrm{C}$ were identified, respectively. Based on the combination with the XRD results and previous studies $[23-25,35]$, the first two peaks of $\mathrm{CoMnNa} / \mathrm{SiO}_{2}$ and $\mathrm{CoM}$ $\mathrm{nNa} / \gamma-\mathrm{Al}_{2} \mathrm{O}_{3}$ correspond to a two-step reduction of $\mathrm{Co}^{3+}$ to $\mathrm{Co}^{2+}$ and $\mathrm{Co}^{2+}$ to metallic $\mathrm{Co}^{0}$. The peak at the higher reduction temperature is mainly due to highly dispersed cobalt species that strongly interact with the oxide support. Notably, the TPR peaks in Fig. 2(a) reveal that the metal-support interaction of $\mathrm{SiO}_{2}$ is stronger than that of $\gamma-\mathrm{Al}_{2} \mathrm{O}_{3}$. The third peak of the $\mathrm{CoMnNa} / \mathrm{SiO}_{2}$ catalyst at $566^{\circ} \mathrm{C}$ is due to the reduction of cobalt silicates [36]. The third peak of $\mathrm{CoMnNa} / \gamma-\mathrm{Al}_{2} \mathrm{O}_{3}$ at $604{ }^{\circ} \mathrm{C}$ corresponds to the reduction of cobalt aluminate species [27,37]. The CoMnNa/CNT catalyst shows two distinct peaks centered at 372 and $447^{\circ} \mathrm{C}$, corresponding to the reduction of $\mathrm{CoO}$ and CoMn composite oxides, respectively.

\subsection{4. (HR)TEM}

The (HR)TEM images of the reduced samples are shown in Fig. 3. Both CoO (with a $d$-spacing of $2.13 \AA$ of the (200) facet) and $\mathrm{MnO}$ (with a $d$-spacing of $2.54 \AA$ of the (111) facet) phases were found in the reduced $\mathrm{CoMnNa} / \mathrm{SiO}_{2}$ sample. The average size of $\mathrm{CoO}$ is only $10.2 \mathrm{~nm}$, with a very narrow distribution (Fig. 3(a3)). Sphere-like nanoparticles were observed in the reduced samples of $\mathrm{CoMnNa} / \gamma-\mathrm{Al}_{2} \mathrm{O}_{3}$ and $\mathrm{CoMnNa} / \mathrm{CNT}$, with a
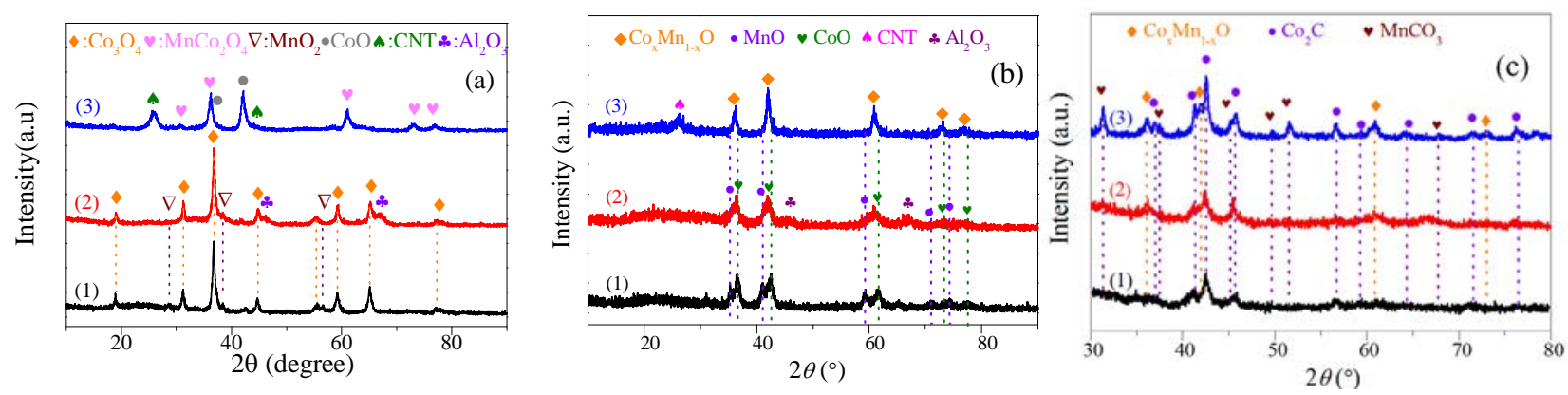

Fig. 1. XRD patterns of various catalysts after calcination (a), reduction (b), and reaction (c). (1) $\mathrm{CoMnNa} / \mathrm{SiO}_{2}$; (2) $\mathrm{CoMnNa} / \gamma-\mathrm{Al}_{2} \mathrm{O}_{3}$; (3) $\mathrm{CoM}-$ $\mathrm{nNa} / \mathrm{CNT}$. 

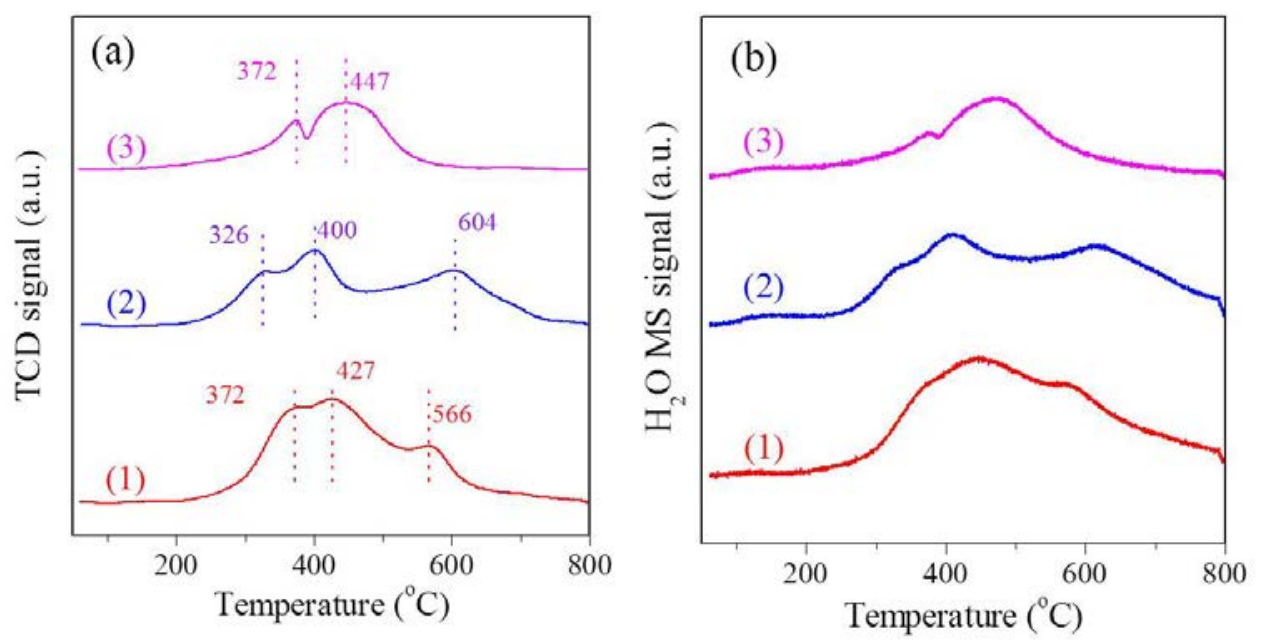

Fig. 2. (a) TPR profiles of various supported catalysts; (b) MS signals of $m / z=18\left(\mathrm{H}_{2} \mathrm{O}\right)$ of the outlet gas during the TPR. (1) $\mathrm{CoMnNa} / \mathrm{SiO}_{2}$; (2) CoM$\mathrm{nNa} / \gamma-\mathrm{Al}_{2} \mathrm{O}_{3} ;$ (3) CoMnNa/CNT.
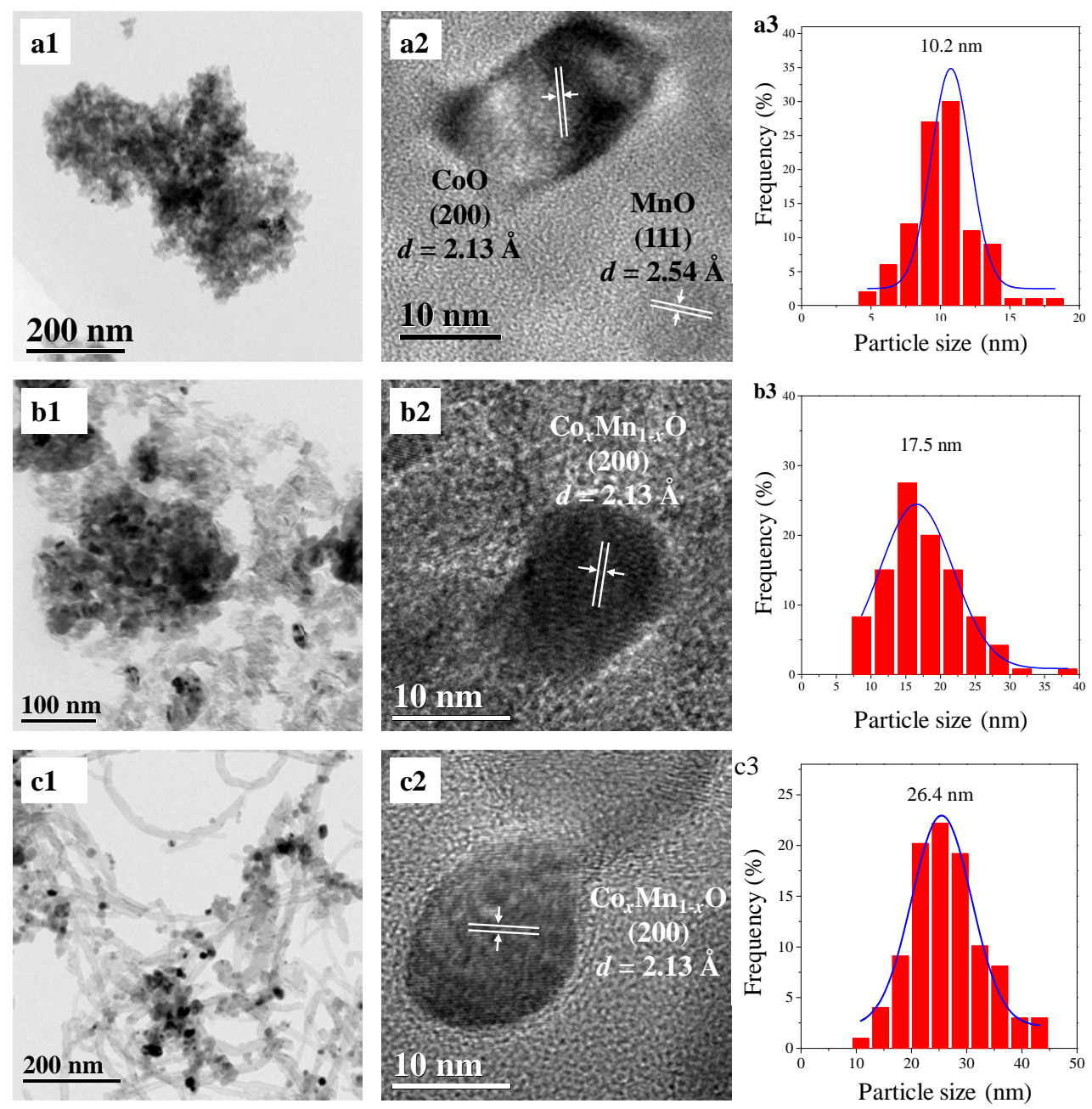

Fig. 3. TEM images ((1) and (2)) and particle size distributions (3) for various reduced supported catalysts. (a) $\mathrm{CoMnNa} / \mathrm{SiO}_{2}$; (b) $\mathrm{CoMnNa} \gamma-\mathrm{Al}_{2} \mathrm{O}_{3}$; (c) CoMnNa/CNT.

size distribution of 5-40 $\mathrm{nm}$. The $d$-spacings of 2.13 and $2.47 \AA$ correspond to the (200) and (111) facets of $\mathrm{Co}_{x} \mathrm{Mn}_{1-x} \mathrm{O}$, respectively. The average particle sizes of $\mathrm{Co}_{x} \mathrm{Mn}_{1-x} \mathrm{O}$ on the $\gamma-\mathrm{Al}_{2} \mathrm{O}_{3}$ and CNT supports are 17.5 and $26.4 \mathrm{~nm}$, respectively, much greater than that on $\mathrm{SiO}_{2}$. In addition, most of the $\mathrm{Co}_{x} \mathrm{Mn}_{1-x} \mathrm{O}$ nanoparticles are located outside of the channels of CNT.

The (HR)TEM images of the spent catalysts are presented in Fig. 4. A large number of spherical nanoparticles from 5 to 30 

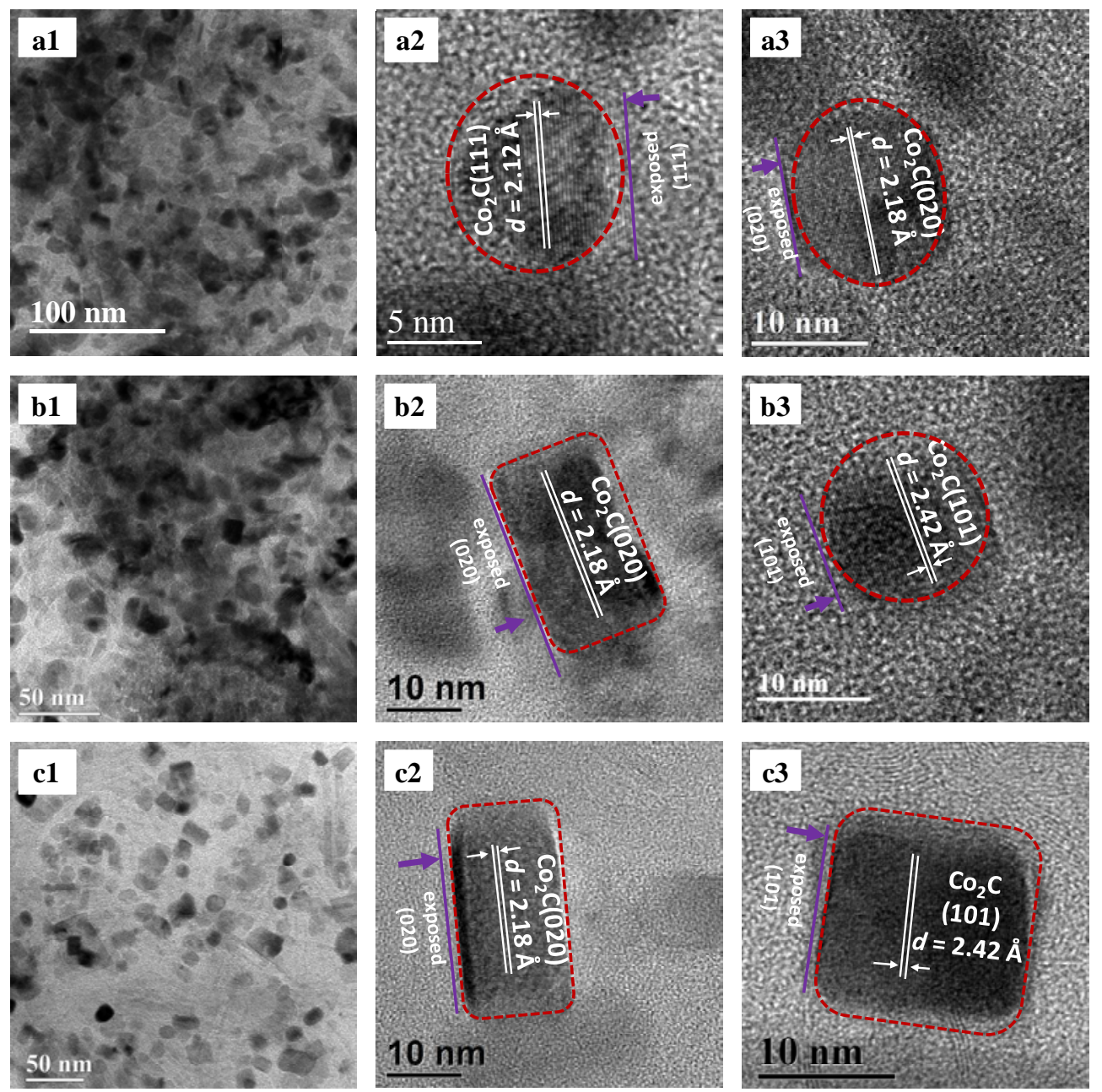

Fig. 4. (HR)TEM images of various spent catalysts. (a) $\mathrm{CoMnNa} / \mathrm{SiO}_{2}$; (b) $\mathrm{CoMnNa} / \gamma-\mathrm{Al}_{2} \mathrm{O}_{3}$; (c) $\mathrm{CoMnNa} / \mathrm{CNT}$.

nm were observed in the $\mathrm{SiO}_{2}$-supported catalyst. Magnified images of randomly selected areas are shown in Fig. 4(a2)-(a3). Nanoparticles with lattice spacings of 2.12 and 2.18 $\AA$ corresponding to the (111) and (020) planes of $\mathrm{Co}_{2} \mathrm{C}$, respectively, were detected. Fig. 4(b1)-(b3) shows the (HR)TEM images of the $\mathrm{CoMnNa} / \gamma-\mathrm{Al}_{2} \mathrm{O}_{3}$ catalyst; both $\mathrm{Co}_{2} \mathrm{C}$ nanospheres and nanoprisms were identified. Many $\mathrm{Co}_{2} \mathrm{C}$ nanoprisms with $d$-spacings of 2.19 and $2.45 \AA$ corresponding to the (020) and (101) exposed facets, respectively, were observed in the CoM-
$\mathrm{nNa}$ /CNT catalyst (Fig. 4(c1)-(c3)), with most of the $\mathrm{Co}_{2} \mathrm{C}$ nanoparticles located outside of the CNT channels.

\subsection{Catalytic performance}

The supported catalysts were evaluated at $265^{\circ} \mathrm{C}$ and 5 bar to determine the influence of the support on the catalytic activity and product selectivity, as shown in Table 2 . With a $\mathrm{H}_{2} / \mathrm{CO}$ ratio of 0.5 , the studied catalysts exhibit similar CO conversions

Table 2

Catalytic FTO reaction performance of various supported catalysts.

\begin{tabular}{|c|c|c|c|c|c|c|c|c|c|c|}
\hline \multirow{2}{*}{ Catalyst } & \multirow{2}{*}{$\mathrm{H}_{2} / \mathrm{CO}$} & \multirow{2}{*}{$X_{\text {Co }}(\mathrm{C} \%)$} & \multirow{2}{*}{$\mathrm{S}_{\mathrm{CO}_{2}}(\mathrm{C} \%)$} & \multicolumn{3}{|c|}{ Product selectivity $\left(\mathrm{C} \%, \mathrm{CO}_{2}\right.$-free) } & \multicolumn{4}{|c|}{ Olefin/paraffin ratio } \\
\hline & & & & Olefins & Oxygenates & Paraffins $\left(\mathrm{CH}_{4}\right)^{\text {a }}$ & $\mathrm{C}_{2}$ & $\mathrm{C}_{3}$ & $\mathrm{C}_{4}$ & $\mathrm{O} / \mathrm{P}$ \\
\hline \multirow[t]{3}{*}{$\overline{\mathrm{CoMnNa} / \mathrm{SiO}_{2}}$} & 0.5 & 10.8 & 35.1 & 68.5 & 11.9 & $19.6(12.0)$ & 4.8 & 12.1 & 9.7 & 3.5 \\
\hline & 1.0 & 32.2 & 38.7 & 64.4 & 9.8 & $25.9(14.5)$ & 1.7 & 8.5 & 6.4 & 2.5 \\
\hline & 2.0 & 63.2 & 36.5 & 50.5 & 10.8 & $38.7(20.4)$ & 0.3 & 4.4 & 4.2 & 1.3 \\
\hline \multirow[t]{3}{*}{$\mathrm{CoMnNa} / \gamma-\mathrm{Al}_{2} \mathrm{O}_{3}$} & 0.5 & 12.2 & 38.1 & 64.7 & 22.7 & $12.6(5.8)$ & 7.2 & 16.9 & 11.9 & 5.1 \\
\hline & 1.0 & 32.7 & 45.1 & 66.2 & 14.0 & $19.8(10.2)$ & 2.3 & 10.9 & 8.1 & 3.3 \\
\hline & 2.0. & 60.6 & 42.3 & 51.5 & 14.7 & $33.8(17.6)$ & 0.6 & 5.3 & 5.0 & 1.5 \\
\hline \multirow[t]{3}{*}{ CoMnNa/CNT } & 0.5 & 12.8 & 46.1 & 66.6 & 25.4 & $7.9(2.4)$ & 12.9 & 16.4 & 10.4 & 8.4 \\
\hline & 1.0 & 26.6 & 50.0 & 60.0 & 27.2 & $12.8(5.4)$ & 5.8 & 10.9 & 7.4 & 4.7 \\
\hline & 2.0 & 42.8 & 48.9 & 54.7 & 26.4 & $18.9(9.2)$ & 3.4 & 8.2 & 5.7 & 2.9 \\
\hline
\end{tabular}

Reaction conditions: $265^{\circ} \mathrm{C}, 5$ bar, $2000 \mathrm{~mL} \mathrm{~h}^{-1} \mathrm{~g}_{\mathrm{cat}^{-1}}$.

a The values in the brackets represent the methane selectivity of the total product. 

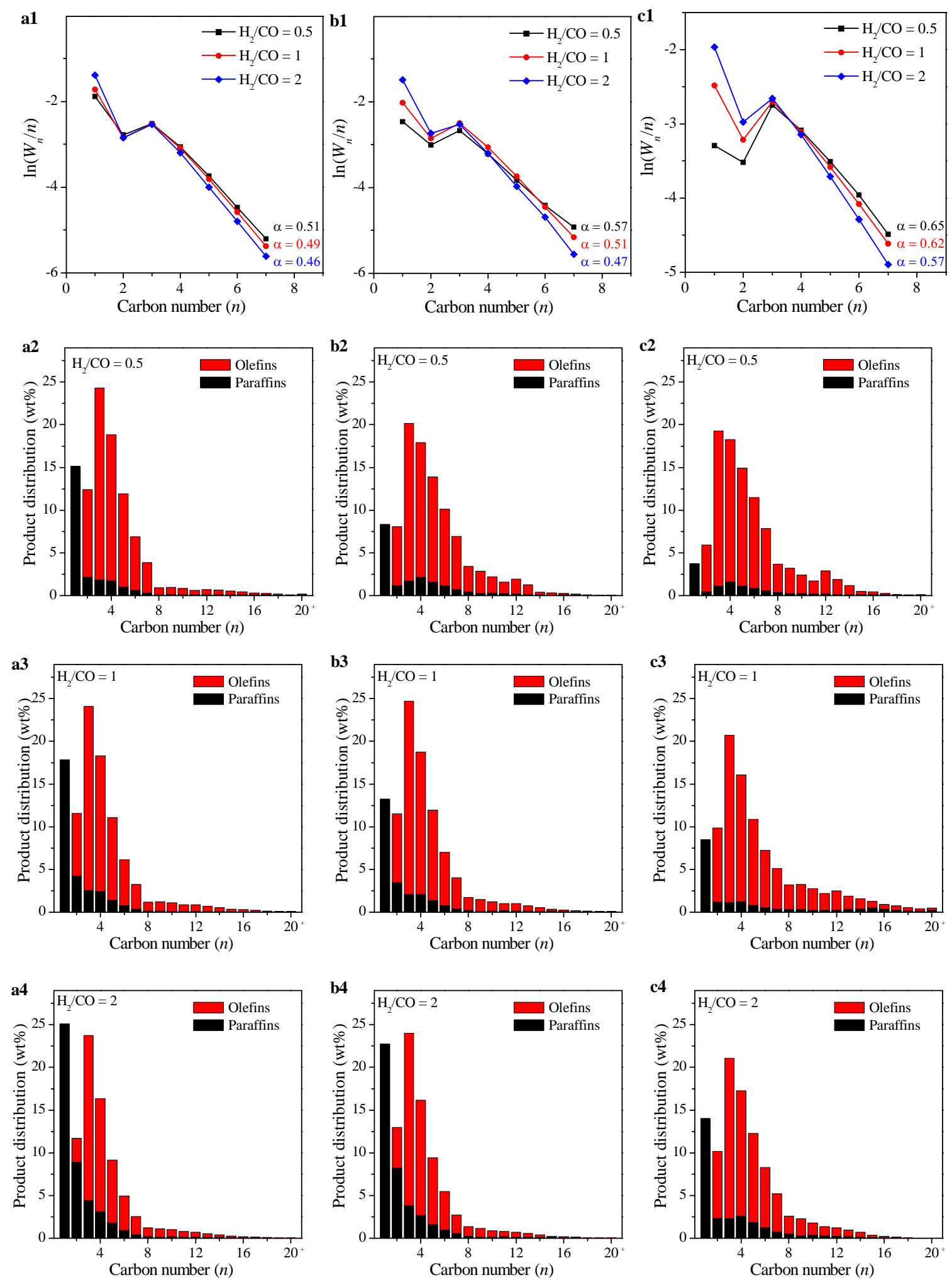

Fig. 5. (1) Hydrocarbon distributions of various supported catalysts with the chain growth probability ( $\alpha$ ) obtained by fitting the results generated for chains of three to seven carbons using the ASF model; (2)-(4) Detailed distributions of hydrocarbons. (a) $\mathrm{CoMnNa} / \mathrm{SiO}_{2}$; (b) $\mathrm{CoMnNa} \gamma_{-} \mathrm{Al}_{2} \mathrm{O}_{3}$; (c) CoMnNa/CNT.

$(10.8 \%-12.8 \%)$, while the product selectivity differs greatly. The $\mathrm{CO}_{2}$ selectivity of various catalysts follows the order CoM$\mathrm{nNa} / \mathrm{SiO}_{2}(35.1 \mathrm{C} \%)<\mathrm{CoMnNa} / \gamma-\mathrm{Al}_{2} \mathrm{O}_{3}(38.1 \mathrm{C} \%)<\mathrm{CoM}-$ $\mathrm{nNa} / \mathrm{CNT}(46.1 \mathrm{C} \%)$. For the FTO process, it is necessary to maximize the olefin fraction and minimize the methane selectivity. Although the $\mathrm{SiO}_{2}$-supported catalyst shows $68.5 \mathrm{C} \%$ of olefin selectivity and $11.9 \mathrm{C} \%$ of oxygenates selectivity, the methane selectivity is too high $(12.0 \mathrm{C} \%)$ and the ratio of olefin 
to paraffin is only 3.5. The olefin and oxygenate selectivities of the $\gamma-\mathrm{Al}_{2} \mathrm{O}_{3}$-supported catalyst are $64.7 \mathrm{C} \%$ and $22.7 \mathrm{C} \%$, respectively, whereas the methane selectivity is $5.8 \mathrm{C} \%$ and the ratio of olefin to paraffin is higher (5.1). The CNT-supported catalyst, however, displays optimal product fractions of olefins and oxygenates. The total olefin and oxygenate selectivities are as high as $92.1 \mathrm{C} \%$ (66.7\% and $25.4 \mathrm{C} \%$, respectively) and the olefin to paraffin ratio reaches 8.4 with the least amount of methane formed $(2.4 \mathrm{C} \%)$.

The detailed hydrocarbon distributions of various catalysts are shown in Fig. 5. A remarkable deviation from the typical ASF distribution was observed for the CNT-supported catalyst. With respect to the $\mathrm{C}_{2}$ component, reabsorption of olefins is the main reason for the much lower value of the $\mathrm{C}_{2}$ component compared with the prediction. However, the hydrocarbon distribution of the $\mathrm{SiO}_{2}$-supported catalyst follows the ASF law, while the $\gamma-\mathrm{Al}_{2} \mathrm{O}_{3}$-supported catalyst slightly deviates from the traditional ASF model. The chain growth probabilities for the $\mathrm{SiO}_{2^{-}}, \gamma-\mathrm{Al}_{2} \mathrm{O}_{3^{-}}$, and CNT-supported catalysts are $0.51,0.57$, and 0.65 , respectively. The slightly higher chain growth probability for the CNT-supported catalyst suggests a stronger chain propagation probability. The hydrocarbon distributions of the catalysts are plotted in Fig. 5(a2), (b2), and (c2). The CNT-supported catalyst shows the highest olefin content, reaching as high as $88.7 \mathrm{wt} \%$ of the total hydrocarbons with a methane fraction of only $3.7 \mathrm{wt} \%$. In addition, the obtained olefins are mainly in the range of $\mathrm{C}_{2}$ to $\mathrm{C}_{12}$, with a $\mathrm{C}_{2-10}$ selectivity as high as $91 \%$, while the $\mathrm{C}_{13+}$ selectivity is as low as $5 \%$, indicating a much narrower distribution. The olefin fraction of the $\mathrm{SiO}_{2}$ - and $\gamma-\mathrm{Al}_{2} \mathrm{O}_{3}$-supported catalysts drops to $76.1 \mathrm{wt} \%$ and $81.4 \mathrm{wt} \%$, respectively. The methane fractions of the $\mathrm{SiO}_{2}$ and $\gamma-\mathrm{Al}_{2} \mathrm{O}_{3}$-supported catalysts are as high as $15.2 \mathrm{wt} \%$ and $8.3 \mathrm{wt} \%$, respectively.

The effect of the $\mathrm{H}_{2} / \mathrm{CO}$ ratio on the catalytic performance was also investigated. Table 2 shows that the CO conversion of all supported catalysts increases with increasing $\mathrm{H}_{2} / \mathrm{CO}$ ratio. However, the olefin selectivity and $\mathrm{O} / \mathrm{P}$ ratio dramatically decrease due to the intensive hydrogenation at a higher $\mathrm{H}_{2} / \mathrm{CO}$ ratio and increasing methane selectivity. For example, at a $\mathrm{H}_{2} / \mathrm{CO}$ ratio of 2, the olefin selectivity decreases to $50.5 \mathrm{C} \%$ over $\mathrm{CoMnNa} / \mathrm{SiO}_{2}$ and the methane and paraffin selectivities increase to $20.4 \mathrm{C} \%$ and $38.7 \mathrm{C} \%$, respectively. The olefin selec-
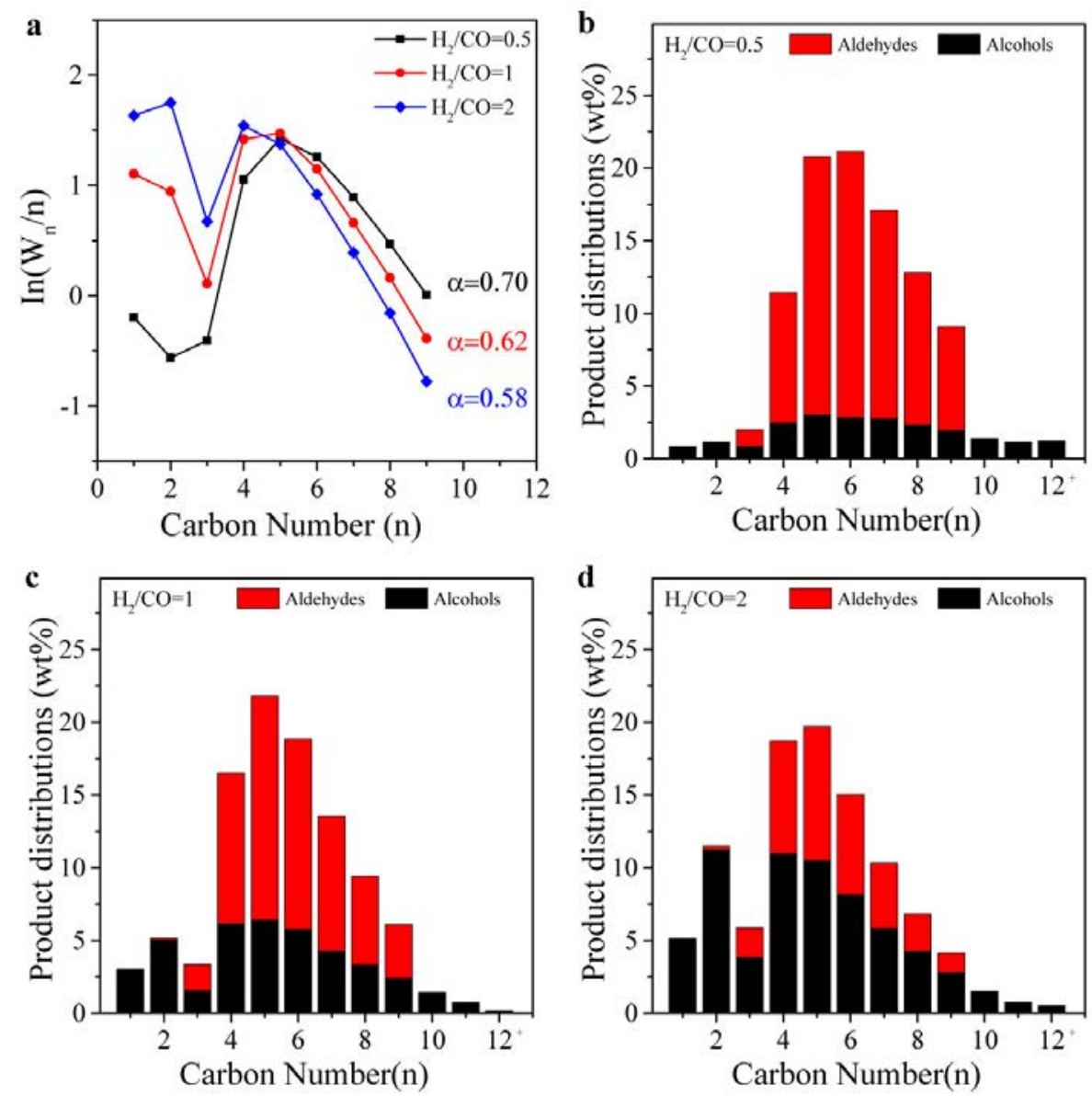

Fig. 6. (a) Oxygenate product distributions of CNT-supported catalysts with different $\mathrm{H}_{2} / \mathrm{CO}$ ratios with the chain growth probability ( $\alpha$ ) obtained by fitting the results generated for chains of five to nine carbons using the ASF model; Oxygenate product distributions at $\mathrm{H}_{2} / \mathrm{CO}$ ratios of (b) 0.5 , (c) 1 , and (d) 2 . 
tivity of the $\gamma-\mathrm{Al}_{2} \mathrm{O}_{3}$-supported catalyst also decreases to $51.5 \%$ and the methane and paraffin selectivities increase to $17.6 \mathrm{C} \%$ and $33.8 \mathrm{C} \%$, respectively. The CNT-supported catalysts still exhibit a promising catalytic performance, even at a higher $\mathrm{H}_{2} / \mathrm{CO}$ ratio. The total olefin and oxygenate selectivities are still as high as $81.1 \mathrm{C} \%$, with a $\mathrm{H}_{2} / \mathrm{CO}$ ratio of 2 . The undesired methane and paraffin selectivities only slightly increase to $9.2 \mathrm{C} \%$ and $18.9 \mathrm{C} \%$, respectively.

The hydrocarbon distributions under various $\mathrm{H}_{2} / \mathrm{CO}$ ratios are plotted in Fig. 5. Due to the enhanced hydrogenation ability under a high $\mathrm{H}_{2} / \mathrm{CO}$ ratio, the chain growth probability decreases. For example, the chain growth probability of the $\mathrm{SiO}_{2}$-supported catalysts decreases from 0.51 to 0.46 as the $\mathrm{H}_{2} / \mathrm{CO}$ ratio increases from 0.5 to 2 . In addition, the olefin fraction in hydrocarbons drops dramatically from $76.1 \mathrm{wt} \%$ to 54.4 wt $\%$ with increasing $\mathrm{H}_{2} / \mathrm{CO}$ ratio of the $\mathrm{SiO}_{2}$-supported catalyst and from $81.4 \mathrm{wt} \%$ to $58.1 \mathrm{wt} \%$ for the $\gamma-\mathrm{Al}_{2} \mathrm{O}_{3}$-supported catalyst. However, the olefin content of the CNT-supported catalyst only slightly decreases from $88.7 \mathrm{wt} \%$ to $72.7 \mathrm{wt} \%$. The methane content of the hydrocarbons also increases with increasing $\mathrm{H}_{2} / \mathrm{CO}$ ratio. At a $\mathrm{H}_{2} / \mathrm{CO}$ ratio of 2 , the methane con- tent of the hydrocarbons of the $\mathrm{SiO}_{2}$ - and $\gamma-\mathrm{Al}_{2} \mathrm{O}_{3}$-supported catalysts increase to $25.1 \mathrm{wt} \%$ and $22.7 \mathrm{wt} \%$, respectively. However, the methane fraction of the CNT-supported catalyst only increases to $14.0 \mathrm{wt} \%$.

In addition to the formation of olefins, a large amount of oxygenates was also detected in the CNT- supported catalyst. Ding et al. [38-41] reported that a high activity and high alcohol selectivity could be obtained on activated carbon-supported cobalt catalysts from syngas via FT reaction. They attributed this to the high dispersion of $\mathrm{Co}$ and the formation of $\mathrm{Co}_{2} \mathrm{C}$ species. The DFT calculations suggest that the activation energies for $\mathrm{CO}$ dissociation of various $\mathrm{Co}_{2} \mathrm{C}$ facets are quite different. In our previous study [35], we showed that $\mathrm{Co}_{2} \mathrm{C}$ nanoparticles with certain exposed facets can act as dual sites for oxygenate formation. The $\mathrm{Co}_{2} \mathrm{C}$ facets with a lower $\mathrm{CO}$ dissociation activation energy might act as the active site to form alkyl species, while those with a higher $\mathrm{CO}$ dissociation activation energy are responsible for $\mathrm{CO}$ insertion. Oxygenate products may be generated at the interface of two adjacent $\mathrm{Co}_{2} \mathrm{C}$ facets with distinct CO dissociation energies. Fig. 6 shows the oxygenate distribution of the $\mathrm{CoMnNa} / \mathrm{CNT}$ catalyst at different $\mathrm{H}_{2} / \mathrm{CO}$ ratios. The
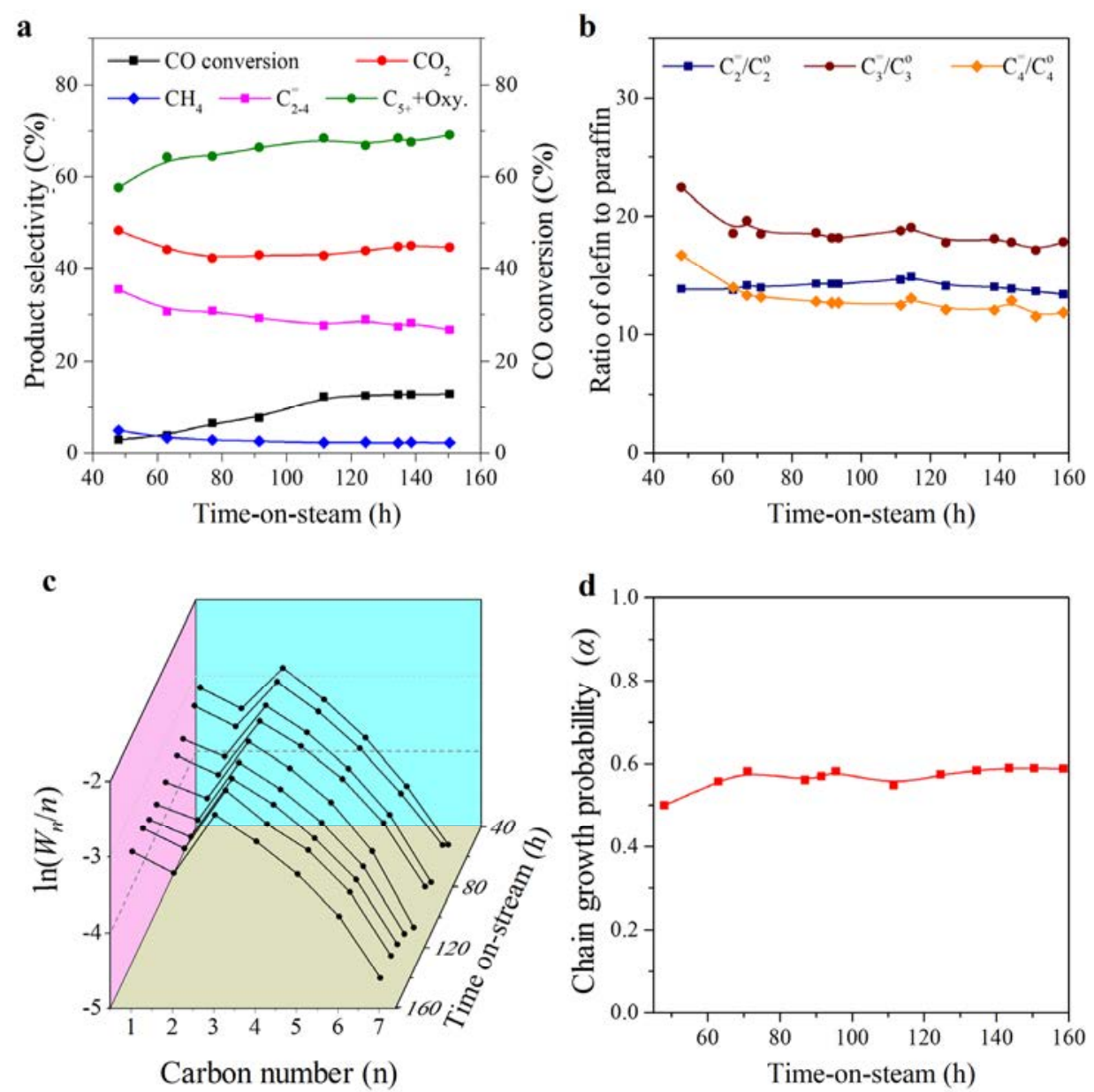

Fig. 7. Catalytic FTO process performance of CoMnNa/CNT catalysts. (a) CO conversion and product selectivity as a function of the time-on-stream; (b Ratio of olefin to paraffin as a function of the time-on-stream; (c) Product plots $\left(\ln \left(W_{n} / n\right)\right.$ and $\left.n\right)$ with the time-on-stream for hydrocarbons; where $W_{n}$ is the weight fraction of a product with $n$ number of carbon atoms; (d) Chain growth probability ( $\alpha$ ) as a function of the time-on-stream obtained by fitting the results generated for chains of three to seven carbons using the ASF model. Reaction conditions: $265^{\circ} \mathrm{C}, 5 \mathrm{bar}, 2000 \mathrm{~mL} \mathrm{~h}^{-1} \mathrm{~g}_{\mathrm{cat}}{ }^{-1}$, and $\mathrm{H}_{2} / \mathrm{CO}$ $=0.5$. 
$\mathrm{C}_{2}-\mathrm{C}_{10}$ oxygenate fraction accounts for more than $93.6 \mathrm{wt} \%$ of all oxygenate products. With the $\mathrm{H}_{2} / \mathrm{CO}$ ratio increasing from 0.5 to 2 , the chain growth probability of the oxygenates decreases from 0.70 to 0.58 and the aldehyde fraction decreases from $78.3 \mathrm{wt} \%$ to $34.6 \mathrm{wt} \%$. In addition, the methanol content increases from $0.8 \mathrm{wt} \%$ to $5.1 \mathrm{wt} \%$.

The catalytic stability of the CNT-supported catalyst was also tested (Fig. 7). After an initial activation period, the CO conversion reaches $12 \mathrm{C} \%$ and no notable deactivation is found within $150 \mathrm{~h}$ of the time-on-stream. The product selectivity remains unchanged with a $\sim 43 \mathrm{C} \% \mathrm{CO}_{2}$ selectivity. With respect to the product selectivity, the methane and $\mathrm{C}_{2-4}=$ selectivities are maintained at approximately $2.2 \mathrm{C} \%$ and $30 \mathrm{C} \%$, respectively, while the $\mathrm{C}_{5+}+$ oxygenate selectivity remains $\sim 56$ $\mathrm{C} \%$. The ratio of $\mathrm{C}_{2}=/ \mathrm{C}_{2}{ }^{\circ}, \mathrm{C}_{3}=/ \mathrm{C}_{3^{\circ}}$, and $\mathrm{C}_{4}=/ \mathrm{C}_{4}{ }^{\circ}$ stays at $\sim 15,19$, and 13, respectively. The hydrocarbon product distribution as a function of the time-on-stream is plotted in Fig. 7(c). The $\ln \left(W_{n} / n\right)$ value of $C_{1}$ shows a significant deviation from the typical ASF distribution and is much lower than the predicted value based on the ASF law. Fig. 7(d) shows the variation of the chain growth probability $(\alpha)$ for hydrocarbons as a function of the time-on-stream. The chain growth probability remains at a value of $\sim 0.58$ during the stability test.

\subsection{Effect of the catalyst support}

Based on the combination of the catalyst characterization and FTO performance, the support has a great effect on the catalyst structure and catalytic properties. The strong metal-support interaction hinders the formation of the CoMn composite oxide, which is required for the generation of the specific $\mathrm{Co}_{2} \mathrm{C}$ morphology [23-25]. Inert CNT contributes to the formation of the CoMn composite oxide during the calcination process, while the $\mathrm{Co}_{3} \mathrm{O}_{4}$ and $\mathrm{MnO}_{2}$ of the $\mathrm{SiO}_{2}$ - and $\gamma$ - $\mathrm{Al}_{2} \mathrm{O}_{3}$-supported catalysts separate. The support also influences the reducibility of the supported catalyst, as shown by the $\mathrm{H}_{2}$-TPR characterization. The reduction temperature of the $\mathrm{SiO}_{2}$-supported catalyst is higher than that of the $\gamma$ - $\mathrm{Al}_{2} \mathrm{O}_{3}$-supported catalysts due to the stronger cobalt-support interaction of the $\mathrm{SiO}_{2}$-supported catalyst. After the reduction, a CoMn composite oxide with low valence was found in the CNT-supported catalyst, while separated phases of $\mathrm{CoO}$ and $\mathrm{MnO}$ were detected in the $\mathrm{SiO}_{2}$-supported catalyst. In addition to $\mathrm{CoO}$ and $\mathrm{MnO}$ phases, low-valence CoMn composite oxide forms in the $\gamma-\mathrm{Al}_{2} \mathrm{O}_{3}$-supported catalysts. The formation of the CoMn composite oxide contributes to the formation of $\mathrm{Co}_{2} \mathrm{C}$ nanoprisms with special, exposed (101) and (020) facets [23-25]. As confirmed by TEM, the CNT-supported catalyst contains many $\mathrm{Co}_{2} \mathrm{C}$ nanoprisms, while most of the $\mathrm{Co}_{2} \mathrm{C}$ nanostructures of the $\mathrm{SiO}_{2}$-supported catalyst are in the form of nanospheres and both $\mathrm{Co}_{2} \mathrm{C}$ nanospheres and nanoprisms are found in the $\gamma-\mathrm{Al}_{2} \mathrm{O}_{3}$-supported catalysts.

Manganese has been reported to be an electronic promoter that alters the chemisorption species on the catalyst surface and a structural promoter that enhances the dispersion of the active phase during the FTO process $[9,42,43]$. The necessity for the addition of Mn during the FTO process was reported in our previous work [23-25]. The Mn acts as a structural promoter and the formation of the CoMn composite oxide precursor benefits the cobalt dispersion. In addition, $\mathrm{Co}_{2} \mathrm{C}$ nanoprisms with special exposed facets can be generated from the CoMn composite oxide in the presence of the sodium promoter. The $\mathrm{Co}_{2} \mathrm{C}$ (101) surface benefits the olefin formation, while the formation of methane on both $\mathrm{Co}_{2} \mathrm{C}(101)$ and $\mathrm{Co}_{2} \mathrm{C}(020)$ is unfavorable. It is well known that $\mathrm{Co}_{2} \mathrm{C}$ nanospheres possess a lower catalytic activity during the FT reaction and the formation of $\mathrm{Co}_{2} \mathrm{C}$ is often considered to be one of the main reasons for the deactivation [44-46]. Notably, $\mathrm{Co}_{2} \mathrm{C}$ nanostructures play an important role in the syngas conversion and morphological control of $\mathrm{Co}_{2} \mathrm{C}$ nanostructures is essential for the selective formation of lower olefins. In this study, many $\mathrm{Co}_{2} \mathrm{C}$ nanoprisms with exposed (020) and (101) facets were found in CoMnNa/CNT, which contributes to the excellent FTO performance with high olefin selectivity and low methane selectivity. On the other hand, most of the $\mathrm{Co}_{2} \mathrm{C}$ species have a spherical morphology, mostly exposing the (111) facet in the spent $\mathrm{CoMnNa} / \mathrm{SiO}_{2}$ catalysts, resulting in a high methane selectivity. We thus conclude that the support has a great influence on the $\mathrm{Co}_{2} \mathrm{C}$ morphology and corresponding catalytic performance.

\section{Conclusions}

A series of CoMn catalysts with different support materials $\left(\mathrm{SiO}_{2}, \gamma-\mathrm{Al}_{2} \mathrm{O}_{3}\right.$, and $\left.\mathrm{CNT}\right)$ were synthesized using the impregnation method. The influence of the support on the FTO reaction was investigated in detail in this study. It was found that the interaction between the support and cobalt species has a great impact on the formation of active $\mathrm{Co}_{2} \mathrm{C}$ sites. Inert CNT facilitates the formation of the CoMn composite oxide, which contributes to the generation of $\mathrm{Co}_{2} \mathrm{C}$ nanoprisms with special, exposed (111) and (020) planes. These $\mathrm{Co}_{2} \mathrm{C}$ nanostructures display an excellent FTO performance. Under conditions of 265 ${ }^{\circ} \mathrm{C}, 5$ bar, $2000 \mathrm{~mL} \mathrm{~h}^{-1} \mathrm{gcat}^{-1}$, and a $\mathrm{H}_{2} / \mathrm{CO}$ ratio of 0.5 , the total selectivity of olefin and oxygenate products is higher than 92 C\% (66.7 C\% and 25.4 C\% for olefins and oxygenates, respectively) and the undesired paraffin product fraction is less than $8 \mathrm{C} \%$. The olefin to paraffin ratio reaches a very high value of 8.4 and the product distribution greatly deviates from the classical ASF distribution, with a methane selectivity of only 2.4 $\mathrm{C} \%$. No notable catalyst deactivation was observed within the 150 test hours. Support materials with high specific surface areas, such as $\mathrm{SiO}_{2}$ and $\gamma-\mathrm{Al}_{2} \mathrm{O}_{3}$, interact strongly with cobalt species and inhibit the formation of the CoMn composite oxide; $\mathrm{Co}_{3} \mathrm{O}_{4}$ and $\mathrm{MnO}_{2}$ were identified in calcined catalysts. After the reduction, $\mathrm{CoO}, \mathrm{MnO}$, and low-valence $\mathrm{CoMn}$ composite oxides are generated in the $\gamma-\mathrm{Al}_{2} \mathrm{O}_{3}$ supported sample. Both $\mathrm{Co}_{2} \mathrm{C}$ nanospheres and nanoprisms were identified in the corresponding spent catalysts, which cause the formation of undesired paraffins with selectivities as high as $12.6 \mathrm{C} \%$. The total olefin and oxygenate product fraction drops to $87.4 \mathrm{C} \%$ and the methane selectivity reaches $5.8 \mathrm{C} \%$. Only a slight deviation from the traditional ASF distribution was found in the $\gamma-\mathrm{Al}_{2} \mathrm{O}_{3}$-supported catalyst. In addition, complete phase separation of $\mathrm{CoO}$ and $\mathrm{MnO}$ was observed in the reduced $\mathrm{SiO}_{2}$-supported sample. In 
the spent $\mathrm{SiO}_{2}$-supported catalyst, $\mathrm{Co}_{2} \mathrm{C}$ nanospheres were detected and $\mathrm{Co}_{2} \mathrm{C}$ nanoprisms were not observed. Although the olefin selectivity is as high as $68.5 \mathrm{C} \%$, the paraffin fraction increases to $19.6 \mathrm{C} \%$, with methane selectivity as high as 12.0 $\mathrm{C} \%$. The product distribution follows the classical ASF distribution. These results suggest that the support material has a great influence on the $\mathrm{Co}_{2} \mathrm{C}$ morphology and the weak cobalt-support interaction benefits the formation of $\mathrm{Co}_{2} \mathrm{C}$ nanoprisms with promising catalytic performance with respect to the sustainable production of olefins via syngas.

\section{References}

[1] H. M. Torres Galvis, K. P. de Jong, ACS Catal, 2013, 3, 2130-2149.

[2] A. Corma, F. V. Melo, L. Sauvanaud, F. Ortega, Catal. Today, 2005, 107, 699-706.

[3] B. P. C. Hereijgers, F. Bleken, M. H. Nilsen, S. Svelle, K. P. Lillerud, M. Bjørgen, B. M. Weckhuysen, U. Olsbye, J. Catal., 2009, 264, 77-87.

[4] H. M. Torres Galvis, J. H. Bitter, C. B. Khare, M. Ruitenbeek, A. I. Dugulan, K. P. de Jong, ChemCatChem, 2012, 4, 835-838.

[5] H. M. Torres Galvis, J. H. Bitter, T. Davidian, M. Ruitenbeek, A. I. Dugulan, K. P. de Jong, J. Am. Chem. Soc., 2012, 134, 16207-16215.

[6] C. K. Rofer-DePoorter, Chem. Rev., 1981, 81, 447-474.

[7] O. Borg, S. Eri, E. Blekkan, S. Storsater, H. Wigum, E. Rytter, A. Holmen, J. Catal., 2007, 248, 89-100.

[8] E. De Smit, B. M. Weckhuysen, Chem. Soc. Rev., 2008, 37, 2758-2781.

[9] A. Dinse, M. Aigner, M. Ulbrich, G. R. Johnson, A. T. Bell, J. Catal,, 2012, 288, 104-114.

[10] D. B. Bukur, C. Sivaraj, Appl. Catal. A, 2002, 231, 201-214.

[11] K. Xiao, Z. H. Bao, X. Z. Qi, X. X. Wang, L. S. Zhong, K. G. Fang, M. G. Lin, Y. H. Sun, Chin. J. Catal., 2013, 34, 116-129.

[12] I. M. Dahl, S. Kolboe, Catal. Lett., 1993, 20, 329-336.
[13] F. Jiao, J. J. Li, X. L. Pan, J. P. Xiao, H. B. Li, H. Ma, M. M. Wei, Y. Pan, Z. Y. Zhou, M. R. Li, S. Miao, J. Li, Y. F. Zhu, D. Xiao, T. He, J. H. Yang, F. Qi, Q. Fu, X. H. Bao, Science, 2016, 351, 1065-1068.

[14] K. Cheng, B. Gu, X. L. Liu, J. C. Kang, Q. H. Zhang, Y. Wang, Angew. Chem. Int. Ed., 2016, 55, 4725-4728.

[15] J. J. Li, X. L. Pan, X. H. Bao, Chin. J. Catal,, 2015, 36, 1131-1135.

[16] P. Tian, Y. X. Wei, M. Ye, Z. M. Liu, ACS Catal., 2015, 5, 1922-1938.

[17] L. S. Chen, Chem. Fertilizer Des., 2008, 46, 3-6.

[18] S. Sartipi, M. Makkee, F. Kapteijn, J. Gascon, Catal. Sci. Technol., 2014, 4, 893-907.

[19] Z. Y. You, W. P. Deng, Q. H. Zhang, Y. Wang, Chin. J. Catal., 2013, 34, 956-963.

[20] P. Zhai, C. Xu, R. Gao, X. Liu, M. Z. Li, W. Z. Li, X. P. Fu, C. J. Jia, J. L. Xie, M. Zhao, X. P. Wang, Y. W. Li, Q. W. Zhang, X. D. Wen, D. Ma, Angew. Chem. Int. Ed., 2016, 55, 9902-9907.

[21] J. X. Xie, H. M. Torres Galvis, A. C. J. Koeken, A. Kirilin, A. I. Dugulan, M. Ruitenbeak, K. P. de Jong, ACS Catal., 2016, 6, 4017-4024.

[22] H. M. Torres Galvis, A. C. J. Koeken, J. H. Bitter, T. Davidian, M. Ruitenbeek, A. I. Dugulan, K. P. de Jong, J. Catal, 2013, 303, 22-30.

[23] L. S. Zhong, F. Yu, Y. L. An, Y. H. Zhao, Y. H. Sun, Z. J. Li, T. J. Lin, Y. J. Lin, X. Z. Qi, Y. Y. Dai, L. Gu, J. S. Hu, S. F. Jin, Q. Shen, H. Wang, Nature, 2016, 538, 84-86.

[24] Z. J. Li, L. S. Zhong, F. Yu, Y. L. An, Y. Y. Dai, Y. Z. Yang, T. J. Lin, S. G. Li, H. Wang, P. Gao, Y. H. Sun, M. Y. He, ACS Catal., 2017, 7, 3622-3631.

[25] Z. J. Li, T. J. Lin, F. Yu, Y. L. An, Y. Y. Dai, S. G. Li, L. S. Zhong, H. Wang, P. Gao, Y. H. Sun, M. Y. He, ACS Catal., 2017, 7, 8023-8032.

[26] P. Munnik, P. E. de Jongh, K. P. de Jong, Chem. Rev., 2015, 115, 6687-6718.

[27] G. Jacobs, T. K. Das, Y. Q. Zhang, J. L. Li, G. Racoillet, B. H. Davis, Appl. Catal. A, 2002, 233, 263-281.

[28] Y. P. Pei, Y. J. Ding, J. Zang, X. G. Song, W. D. Dong, H. J. Zhu, T. Wang, W. Chen, Chin. J. Catal., 2015, 36, 252-259.

[29] R. C. Reuel, C. H. Bartholomew, J. Catal., 1984, 85, 78-88.

\section{Graphical Abstract}

Chin. J. Catal., 2018, 39: 1869-1880 doi: 10.1016/S1872-2067(18)63153-5

Effect of the support on cobalt carbide catalysts for sustainable production of olefins from syngas

Xinxing Wang, Wen Chen, Tiejun Lin, Jie Li, Fei Yu, Yunlei An, Yuanyuan Dai, Hui Wang, Liangshu Zhong*, Yuhan Sun

Shanghai Advanced Research Institute, Chinese Academy of Sciences; University of Chinese Academy of Sciences; ShanghaiTech University
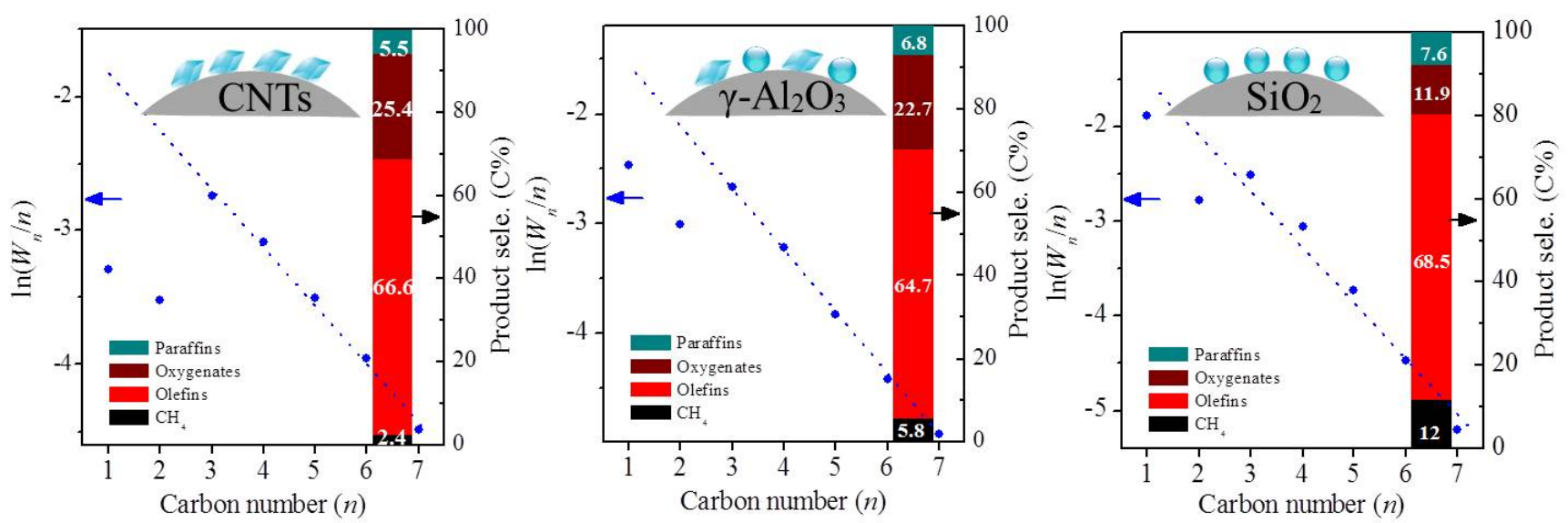

The cobalt-support interaction has a great impact on the $\mathrm{Co}_{2} \mathrm{C}$ morphology and catalytic performance of the Fischer-Tropsch to olefin reaction. 
[30] K. Keyvanloo, M. K. Mardkhe, T. M. Alam, C. H. Bartholomew, B. F. Woodfield, W. C. Hecker, ACS Catal., 2014, 4, 1071-1077.

[31] G. Prieto, M. I. S. De Mello, P. Concepción, R. Murciano, S. B. C. Pergher, A. N. MartíNez, ACS Catal., 2015, 5, 3323-3335.

[32] J. C. Groen, L. A. A. Peffer, J. Pérez-RamíRez, Microporous Mesoporous Mater, 2003, 60, 1-17.

[33] K. Xiao, X. Z. Qi, Z. H. Bao, X. X. Wang, L. S. Zhong, K. G. Fang, M. G. Lin, Y. H. Sun, Catal. Sci. Technol., 2013, 3, 1591-1602.

[34] A. Y. Khodakov, A. Griboval-Constant, R. Bechara, V. L. Zholobenko, J. Catal., 2002, 206, 230-241.

[35] Y. Z. Yang, T. J. Lin, X. Z. Qi, F. Yu, Y. L. An, Z. J. Li, Y. Y. Dai, L. S. Zhong, H. Wang, Y. H. Sun, Appl. Catal. A, 2018, 549, 179-187.

[36] A. M. Saib, M. Claeys, E. van Steen, Catal. Today, 2002, 71, 395-402.

[37] G. L. Bezemer, J. H. Bitter, H. P. C. E. Kuipers, H. Oosterbeek, J. E. Holewijn, X. D. Xu, F. Kapteijn, A. J. van Dillen, K. P. de Jong, J. Am. Chem. Soc., 2006, 128, 3956-3964.
[38] G. P. Jiao, Y. J. Ding, H. J. Zhu, X. M. Li, J. W. Li, R. H. Lin, W. D. Dong, L. F. Gong, Y. P. Pei, Y. Lu, Appl. Catal. A, 2009, 364, 137-142.

[39] Y. P. Pei, Y. J. Ding, H. J. Zhu, J. Zang, X. G. Song, W. D. Dong, T. Wang, L. Yan, Y. Lu, React. Kinet. Mech. Catal., 2014, 111, 505-520.

[40] Z. Zhao, W. Lu, R. Yang, H. J. Zhu, W. D. Dong, F. F. Sun, Z. Jiang, Y. Lyu, T. Liu, H. Du, Y. J. Ding, ACS Catal., 2017, 8, 228-241.

[41] Z. Zhao, W. Lu, H. J. Zhu, W. D. Dong, Y. Lyu, T. Liu, X. K. Chen, Y. Q. Wang, Y. J. Ding, J. Catal., 2018, 361, 156-167.

[42] G. R. Johnson, A. T. Bell, J. Catal., 2016, 338, 250-264.

[43] M. Dad, H. O. A. Fredriksson, J. V. de Loosdrecht, P. C. Thüne, J. W. Niemantsverdriet, Catal. Struct. React, 2015, 1, 101-109.

[44] J. C. Mohandas, M. K. Gnanamani, G. Jacobs, W. P. Ma, Y. Y. X. Ji, S. Khalid, B. H. Davis, ACS Catal., 2011, 1, 1581-1588.

[45] J. Cheng, P. Hu, P. Ellis, S. French, G. Kelly, C. M. Lok, J. Phys. Chem. C, 2010, 114, 1085-1093.

[46] M. Claeys, M. E. Dry, E. van Steen, E. du Plessis, P. J. van Berge, A. M. Saib, D. J. Moodley, J. Catal., 2014, 318, 193-202.

\title{
合成气直接制烯烃碳化钴基催化剂的载体效应
}

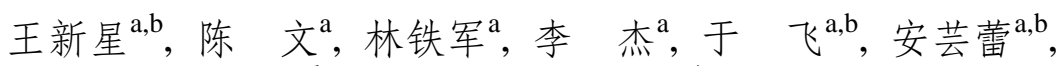 \\ 代元元 ${ }^{\mathrm{a}, \mathrm{b}}$ ，王 慧 ${ }^{\mathrm{a}}$, 钟良枢 ${ }^{\mathrm{a}, \mathrm{c}, *}$ ，孙予罕 ${ }^{\mathrm{a}, \mathrm{c}}$ \\ $\mathrm{a}$ 中国科学院上海高等研究院, 中国科学院低碳转化科学与工程重点实验室, 上海201203 \\ $\mathrm{b}$ 中国科学院大学, 北京 100049 \\ ' 上海科技大学物质科学与技术学院, 上海201203
}

摘要: 烯烃是重要的化工原料, 一般采用石油热裂解和催化裂解制备. 随着石油资源的枯竭, 以煤、天然气和生物质等含碳 资源经合成气制取烯烃的工艺路线备受关注. 其中, 合成气经由甲醇或二甲醚间接制取烯烃技术(MTO)已实现工业化应 用. 与之相比, 费托合成直接生产烯烃(FTO)工艺具有流程短、投资和运行费用低等优势, 具有良好的工业发展前景. 最近 我们发现, 暴露特定晶面的棱柱状碳化钴表现出很好的合成气制烯烃催化性能, 但载体对催化剂结构和催化性能的影响尚 不清晰.

本文采用浸渍法制备了一系列负载型钴锰催化剂, 系统考察了 $\mathrm{SiO}_{2}, \gamma-\mathrm{Al}_{2} \mathrm{O}_{3}$ 和碳纳米管 $(\mathrm{CNT})$ 对催化剂结构及合成气 直接制烯烃催化性能的影响. 结果表明, $\mathrm{SiO}_{2}$ 及 $\gamma-\mathrm{Al}_{2} \mathrm{O}_{3}$ 负载的催化剂较强的钴-载体相互作用抑制了钴锰复合氧化物的形 成, 而相对惰性的CNT载体则有利于钴锰复合氧化物的生成. 通过对反应后催化剂的结构表征, 发现 $\mathrm{SiO}_{2}$ 和 $\gamma-\mathrm{Al}_{2} \mathrm{O}_{3}$ 负载的 催化剂中出现大量球状的碳化钴颗粒, 而CNT负载催化剂中的碳化钴则呈现出具有(101)和(020)暴露晶面的纳米棱柱状结 构. 将所制备的催化剂用于FTO反应, 在 $265{ }^{\circ} \mathrm{C}, 5 \mathrm{bar}$, 空速 $2000 \mathrm{~mL} \mathrm{~h}^{-1} \mathrm{~g}_{\mathrm{cat}}{ }^{-1}$ 和 $\mathrm{H}_{2} / \mathrm{CO}=0.5$ 的反应条件下, CNT负载的催化 剂表现出最佳的催化性能, 烯烃和含氧化合物的选择性分别为 $66.7 \mathrm{C} \%$ 和 $25.4 \mathrm{C} \%$, 甲烷的选择性仅为 $2.4 \mathrm{C} \%$, 总的烯烃/烷 烃比达到8.4, 同时烃类产物分布极大地偏离传统ASF线性分布. 而对于 $\mathrm{SiO}_{2}$ 和 $\gamma-\mathrm{Al}_{2} \mathrm{O}_{3}$ 负载的催化剂, 虽然烯烃的选择性也 分别达到 $68.5 \mathrm{C} \%$ 和 $64.7 \mathrm{C} \%$, 但甲烷的选择性却升至12.0 C\%和5.8 C\%, 总的烯烃/烷烃比仅为3.5和 5.1 , 烃类产物分布基本 符合传统的ASF分布. 在150 h的催化剂测试中, CNT负载催化剂表现出很好的催化性能稳定性, 甲烷的选择性稳定在 2.2 $\mathrm{C} \%, \mathrm{C}_{2}-\mathrm{C}_{4}$ 烯烃的选择性约为 $30 \mathrm{C} \%, \mathrm{C}_{2}, \mathrm{C}_{3}$ 和 $\mathrm{C}_{4}$ 烯烃烷烃比分别稳定在 15,19 和13.

本研究表明, 钴-载体相互作用对碳化钴活性相结构及催化性能具有很大影响, 惰性的催化剂载体有利于钴锰复合氧 化物的生成, 进而促进碳化钴纳米棱柱状结构的形成, 从而表现出优异的合成气直接制烯烃催化性能.

关键词：费托合成制烯烃; 碳化钴; 负载型催化剂; 烯烃; 合成气

收稿日期: 2018-07-02. 接受日期: 2018-07-31. 出版日期: 2018-12-05.

*通讯联系人. 电话: (021)20608002; 传真: (021)20350867; 电子信箱: zhongls@sari.ac.cn

基金来源：国家重点研发计划(2017YFB0602202); 国家自然科学基金(21573271, 91545112, 21703278); 中国科学院前沿科学重点 研究计划(QYZDB-SSW-SLH035); 中国科学院战略性先导科技专项(XDA21020600); 中国科学院上海高等研究院交叉学科青年 创新基金(171001).

本文的电子版全文由Elsevier出版社在ScienceDirect上出版(http://www.sciencedirect.com/science/journal/18722067). 